\title{
THE IMPLEMENTATION OF NON-SMOKING AREA POLICY AT THE ELEMENTARY SCHOOL, PADANGSIDIMPUAN, NORTH SUMATERA
}

\author{
Normayanti Rambe, Ida Yustina, Destanul Aulia \\ Masters Program in Public Health, Faculty of Public Health, \\ Universitas Sumatera Utara
}

\begin{abstract}
Background: The Local Regulation of Padangsidimpuan City No. 7/ 2012 on Non-Smoking Area is a derivative of the Law No. 36/ 2009 on Health and Government Regulation No. 109/ 2012 on Addictive Substance and Tobacco Products Hazardous to Health. The non-smoking area regulation can help the city government of Padangsidimpuan to realize a healthy society. This study aimed to analyze the implementation of the Non-Smoking Area (NSA) policy at public elementary school in Padangsidimpuan City, North Sumatera.

Subjects and Method: This was a qualitative study with phenomenology approach. This study was conducted at the Public Elementary School in Padangsidimpuan city, North Sumatera. Five informants were selected in this study including the principal, teachers, parents, school guards, and food sellers. The data were collected by interview, direct observation, and documentation. The data were analyzed by Miles and Huberman model.

Results: The NSA policy had not been well-implemented at the elementary school, due to some reasons: (1) Lack of communication between the local goverment and the school; (2) Lack of facilities and infrastructure to support the NSA policy; (3) Lack of the law inforcement.

Conclusion: The NSA policy has not been well-implemented at the elementary school because the system is not well-prepared.

Keywords: implementation, non-smoking area policy, elementary school

\section{Correspondence:}

Normayanti Rambe. Masters Program in Public Health, Faculty of Public Health, Universitas Sumatera Utara, Jl. Universitas No. 21, Kampus USU, Medan 20115. Email: Normayantirambe89@gmail.com.
\end{abstract}

Mid-International Conference on Public Health, 